\title{
The Otter in Britain-a Second Report
}

In May 1969 we published the Mammal Society's report on the status of otters in Britain. This was based on figures supplied by otter hunts covering a large part, but not all, of England and southern Scotland. This second report, based on data collected in the same way, was compiled by Professor H. R. Hewer, who fortunately had completed this draft before his untimely death last February. Unfortunately, one hunt, in the north-east, was unable to supply any comparable figures, but for the areas covered-see the map opposite - this second report provides a valuable comparison. It shows that in some counties, in the four years 1968-71, otters have held their own or increased slightly, but in the Midlands especially the decline continues, and the otter can truthfully be described as a locally endangered species.

In 1973, four years after the first Otter Report, the Mammal Society asked otter hunts in England, Wales and Scotland to supply information so that a comparison could be made with the previous figures. This Report rests on data from 10 of the 11 hunts which contributed to the 1969 Report-the missing one, Northern Counties, suffered a period of reorganisation which rendered the new data unsuitable for comparison. Three of the 10 also gave figures for 1972; these have not been used in estimating averages but are recorded to show that they are not incompatible with the earlier data or with the conclusions drawn therefrom.

As in the previous Report the basic figures used for estimating the otter's relative status in the different hunt territories are the 'Finds per 100 days Hunting' - see Table 1. Figures for 1957 and 1967,

TABLE 1 Finds per 100 days hunting

$\begin{array}{lrlllllllr}\text { Dumfriesshire } & 94 & 85 & 85 & 73 & 62 & 81 & \mathbf{( 8 8 )} & \mathbf{7 5} & \text { n.c. } \\ \text { Kendal and District } & 36 & 46 & 30 & 16 & 41 & 59 & - & 36 & \text { n.c. } \\ \begin{array}{l}\text { Border Counties } \\ \text { Pembroke and }\end{array} & 58 & 57 & 68 & 90 & 61 & 98 & - & 79 & + \\ \quad \text { Carmarthen } & 32 & 26 & 43 & 27 & 35 & 72 & (131) & 44 & + \\ \text { Hawkstone } & 126 & 68 & 77 & 62 & 64 & 67 & (49) & 68 & \text { n.c. } \\ \text { Buckinghamshire } & 55 & 44 & 25 & 21 & 20 & 16 & - & 21 & - \\ \text { Eastern Counties } & 70 & 32 & 26 & 38 & 48 & 39 & - & 38 & \text { n.c. } \\ \text { Dartmoor } & 76 & 14 & - & 31 & 23 & 34 & - & 29 & + \\ \text { Culmstock } & 75 & 47 & 39 & 48 & 43 & 53 & - & 46 & \text { n.c. } \\ \text { Courtney Tracey } & 82 & 35 & 41 & 29 & 36 & 30 & - & 34 & \text { n.c. } \\ & 72 & 44 & 48 & 42 & 43 & 55 & - & 47 & \end{array}$


when most of the dramatic decreases in otter populations were taking place, are included (from the 1969 Report) in the two left-hand columns for comparison. The average number of finds per 100 days hunting are set out in the last column but one on the right. Before making an appraisal of the value of these average figures it is desirable to examine the yearly returns per hunt for the years 196871 (and 1972 where known) and also the variations in the returns at 10-yearly intervals recorded in the previous Report.

Dumfriesshire: An average of 75 and records of 94 and 85 for 1957 and 1967 respectively might be thought to indicate a decrease. However, in the most recent five years the figures range from 62 to 88 while in the previous Report they ranged from 64 to 94 . The conclusion is therefore that the status remains constant (n.c. $=$ no change).

Kendal and District: Although the last record of 59 (1971) might indicate a temporary increase in the population, comparison of all the figures available suggests that there has been no change (n.c.).

Border Counties: This area undoubtedly shows a clear recovery-the figures for 1937 and 1947 were 71 and 71 . It may be confidently stated there has been a considerable increase in numbers over those of the 1960 s ( + .

Pembroke and Carmarthen: Here again there are indications of a return to previous numbers. The highest record in the previous Report was 73 for 1937 and the returns for 1971 and 1972 suggest that the population has increased considerably since the 1957-67 decade $(+)$.

Hawkstone: The conclusion is that there has been little radical change of status in this area (n.c.).

Buckinghamshire: There has been a further fall in this area, forecast to some extent by the 1967 figure, the master's comment that the otter is now 'rather rare' is undoubtedly justified. Two developments have adversely affected otters: great pollution of the Midland rivers and an enormous increase in coarse-fish angling. There has undoubtedly been a continuation of the previously recorded decrease $(-)$.

Eastern Counties: Although the average figure of 38 is a slight increase on 32 it is probably without significance overall. Numbers vary greatly in different parts of the area, Norfolk heading the list with Essex at the bottom. It would appear that the otter may well be holding its own or even increasing in the Norfolk area but, with increasing urbanisation in the south, to be losing ground there, resulting in an overall no change (n.c.).

Dartmoor: The average figure of 29 seems to be fairly representative, and a marked increase on the all-time low of 14 in 


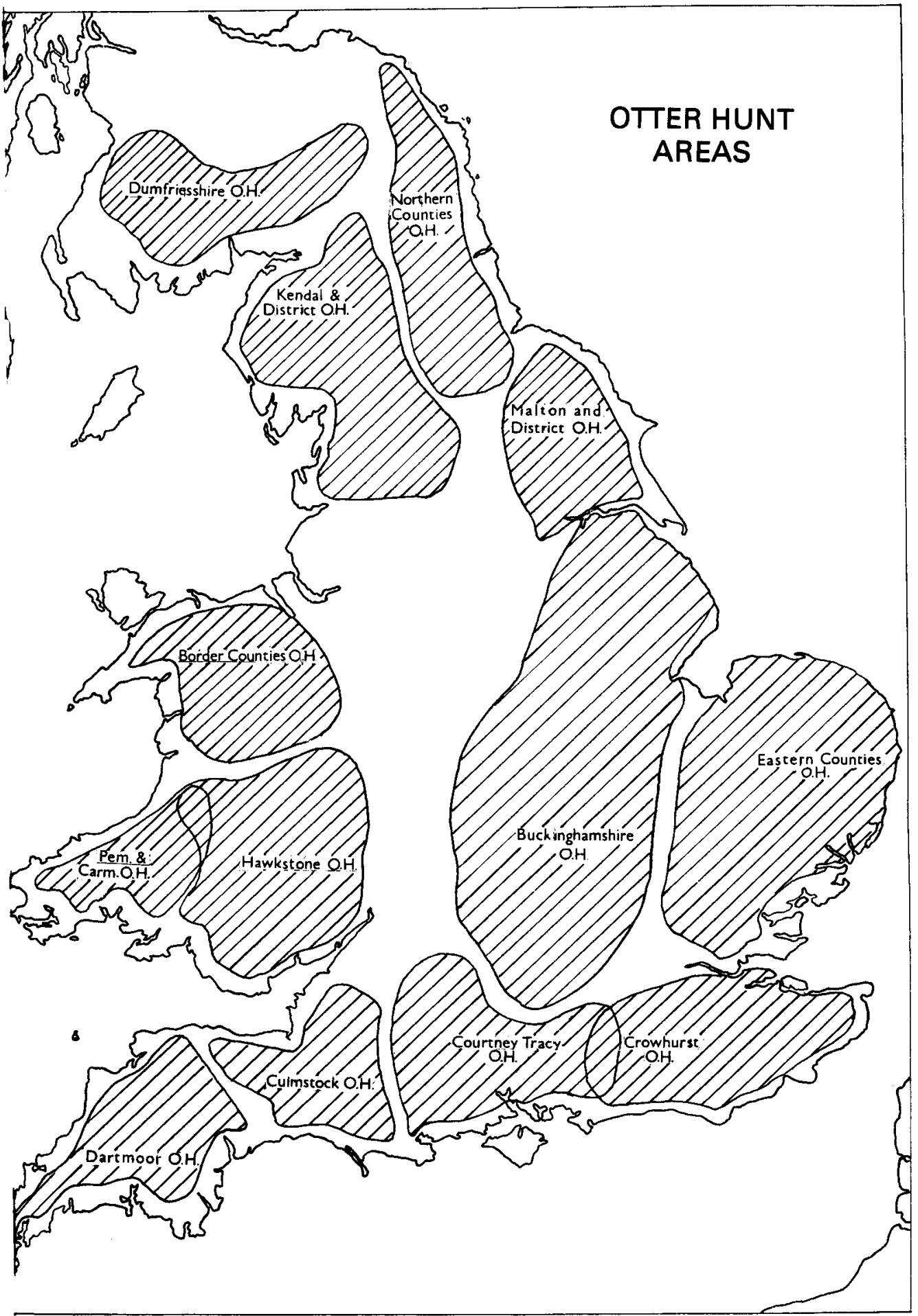


1967. Previous figures show considerable variation over the years (65 in 1937 and 33 in 1947), but there seems justification for believing that there has been a considerable return of numbers. The area is heavily invaded by mink, and it remains to be seen whether there is direct competition between the two species $(t)$.

Culmstock: Here again the average of 46 seems to be fairly representative and indicates no change from the 47 of 1967. Figures of 90 and 93 in 1937 and 1947 respectively show that at one time this was good otter country. Here again a high population of mink is established but there is no evidence of its effects, if any, on that of the otter (n.c.).

Courtney Tracey: Exactly the same comments may be made for this Hunt's area as for that of the Culmstock - no change (n.c.).

\section{Conclusions}

The overall picture giving an average of 54 for the four years 196871 shows a significant increase over 44 for 1967 . Nevertheless, for much of the country there has been no return to former abundance, and for the Midland area there has been a continued decrease. The areas showing any increase are all in the west, and only one of them (Dartmoor) had suffered a previous severe decline. For the Culmstock, Courtney Tracey and Eastern Counties areas, all of which had shown a previous decline, the position has not materially altered. However, since there has not been any further overall significant decline there is some hope that an increase may occur at least in those parts with favourable habitats. The two northern areas showing no change had not been previously affected and therefore there is no cause for alarm at the absence of any definite increase (Dumfriesshire and Kendal). The Hawkstone area whose figures suggest a high population may also be placed in this category.

The remaining one (Buckinghamshire) which covers most of the Midlands and Lincolnshire continues to give concern. The area has a high proportion of the most polluted and sluggish streams as well as suffering from a great deal of human disturbance. It remains to be seen whether the measures being taken to reduce the pollution will be sufficient to result in an increase in otters, despite the clearance of river banks and other disturbances associated with coarse-fishing.

Hunt Masters were asked to make an estimate (subjective) of the abundance of otters in their respective areas. To find a relatively objective basis for comparison the range of finds per 100 days hunting was equated with the range of their verbal estimates, thus:-

$\begin{array}{llll}\text { Very common } & \text { Rather rare } & \text { over } 100 & 5 \\ \text { Common } & \text { Rare } & 60-100 & 4 \\ \text { Fairly common } & 30-60 & 3 \\ & & 10-30 & 2 \\ & & \text { less than } 10 & 1\end{array}$

The last column consists of the scores for each of the categories 
TABLE 2 Scorings for Abundance

'37-'57 '67 '68-'71 Masters'

Dumfriesshire

Kendal and District

Border Counties

Pembroke and Carmarthen

Hawkstone

Buckinghamshire

Eastern Counties

Dartmoor

Culmstock

Courtney Tracey

$\begin{array}{llll}4 & 4 & 4 & 4 \\ 3 & 3 & 3 & 3 \\ 4 & 3 & 4 & 4 \\ 3 & 2 & 3 & 2 \\ 5 & 4 & 4 & 3 \\ 3 & 3 & 2 & 2 \\ 4 & 3 & 3 & 4 \\ 4 & 2 & 2 & 3 \\ 4 & 3 & 3 & 3 \\ 4 & 3 & 3 & 3\end{array}$

used in the construction of Table 2. Comparison of the figures in columns 1 and 3 shows that the first four areas (north and west) now fall into the same categories as they did in the period 1937-1957, the third and fourth having restored the drop of one category found in 1967. The Master's estimate in the first three agrees with the objective estimate, but that of the fourth is too low according to the scale used above. This latter indicated an increase in 1968-71 compared with 1967 which accords with the scoring in the Table. In the other six areas the scorings in columns 1,2 and 3 reflect the conclusions reached above, but two of the Masters have overestimated the population according to the scale: both thought that there had been considerable increase. On Dartmoor the figures suggest an increase of 100 per cent, but this still just fails to place it in category 3 . In the Eastern Counties the numbers in Norfolk may have influenced the subjective score. The numerical increase is only 18 per cent and needs to be maintained to be considered significant. Despite these discrepancies, none of them serious, six out of the ten subjective estimates were correct by comparison with the objective.

In the four years a total of 79 kills has been recorded for the 10 hunts. These data may be divided into the restricted and partially restricted areas.* For the seven hunts in the restricted areas the total kill was 20, which amounts to three per hunt in four years, or 0.7 per hunt per year. In the three remaining hunts in the partially restricted areas, the total was 59 , making 20 per hunt in four years, or five per hunt per year.

In 1967 the percentage of kills to finds was 22.4. This may be compared with the overall figure of 3.8 per cent from 1967-71. In the partially restricted areas alone the figure is 5.0 per cent. Of the 39 hunt-years recorded 14 had no kills and 12 only one.

Asked whether trapping and/or shooting were used in their area, six Masters replied that they believed that they were, largely to protect fishing interests; two others thought it probable but had no proof, and two stated 'none known'. Similarly five believed that * Restricted areas are those in which the hunt called off hounds before making a kill. 
TABLE 3 Data on Mink

\begin{tabular}{|c|c|c|c|c|c|}
\hline & Status & $\begin{array}{l}\text { Earliest } \\
\text { record }\end{array}$ & Change & Policy & $\begin{array}{l}\text { Difficulty } \\
\text { to Hunts }\end{array}$ \\
\hline Dumfriesshire & $\begin{array}{l}\text { Fairly } \\
\text { common }\end{array}$ & $\begin{array}{l}1958 \text { in } \\
\text { Kirkcud. } \\
1970 \text { in } \\
\text { Dumfries }\end{array}$ & $\begin{array}{l}\text { Increased } \\
\text { considerably }\end{array}$ & $\begin{array}{c}\text { Kill by } \\
\text { all means }\end{array}$ & None \\
\hline $\begin{array}{l}\text { Kendal and } \\
\text { District }\end{array}$ & $\begin{array}{l}\text { Very } \\
\text { common }\end{array}$ & $\begin{array}{c}1968 \\
\text { (April) }\end{array}$ & $\begin{array}{l}\text { Increased } \\
\text { considerably }\end{array}$ & $\begin{array}{c}\text { Kill if } \\
\text { possible }\end{array}$ & $\begin{array}{l}\text { Mink in } \\
\text { otter holts }\end{array}$ \\
\hline Border Counties & Absent & - & - & - & - \\
\hline $\begin{array}{l}\text { Pembroke and } \\
\text { Carmarthen }\end{array}$ & $\begin{array}{l}\text { Very } \\
\text { common }\end{array}$ & c. 1963 & $\begin{array}{l}\text { Increased } \\
\text { considerably }\end{array}$ & $\begin{array}{c}\text { Not } \\
\text { hunted }\end{array}$ & Not great \\
\hline Hawkstone & $\begin{array}{l}\text { Fairly } \\
\text { common }\end{array}$ & $1963 / 4$ & $\begin{array}{l}\text { Increased } \\
\text { considerably }\end{array}$ & $\begin{array}{l}\text { Kill if } \\
\text { possible }\end{array}$ & $\begin{array}{l}\text { Disturbance of } \\
\text { breeding holts }\end{array}$ \\
\hline Buckinghamshire & Absent & - & 一 & - & - \\
\hline Eastern Cou & Absent & - & - & - & - \\
\hline Dartm & $\begin{array}{l}\text { Fairly } \\
\text { common }\end{array}$ & 1968 & Stationary & $\begin{array}{l}\text { Kill by } \\
\text { all means }\end{array}$ & $\begin{array}{l}\text { ? Kill otter } \\
\text { cubs }\end{array}$ \\
\hline Culmstoc & $\begin{array}{l}\text { Very } \\
\text { common }\end{array}$ & 1962 & $\begin{array}{c}\text { Increased } \\
\text { considerably }\end{array}$ & $\begin{array}{l}\text { Kill by } \\
\text { all means }\end{array}$ & None \\
\hline Courtn & $\begin{array}{l}\text { Very } \\
\text { common }\end{array}$ & $1963 / 4$ & $\begin{array}{l}\text { Increased } \\
\text { considerably }\end{array}$ & $\begin{array}{c}\text { Kill if } \\
\text { possible }\end{array}$ & $\begin{array}{c}\text { Mink common, } \\
\text { otter scarce }\end{array}$ \\
\hline
\end{tabular}

otters were occasionally shot for pelts, and three others thought it probable but had no proof.

\section{Relations with Mink}

Since the previous Otter Report the Ministry of Agriculture, Fisheries and Food have ceased direct action against the mink on the assumption that it cannot be exterminated (as the musk-rat was) and that consequently it must be considered as a permanent, introduced, member of the fauna and controlled accordingly. The question naturally arises as to what ecological niche the mink will occupy. While its closest relatives are the stoat and weasel their habitats are very different. It would seem that ecologically the mink would come into competition with the otter, since both species are carnivores based on rivers and lakes. Nevertheless their total requirements may not be the same and they may be able to co-exist without difficulty, although the numbers of either might not attain the same height as they would in the absence of the other. In North America, the home of the mink, the Canadian otter, an extremely close relative of our species, lives in harmony with the mink. The two species have almost identical distributions over nearly all of Canada and the United States. It was thought desirable to collect information regarding the mink, especially in its relation to man's activities, and Table 3 summarises the replies.

\section{Mink Distribution}

Mink are certainly found in seven of the 10 areas and have become fairly to very common, increasing markedly over the years; six of the seven hunts in these areas kill them whenever possible and 
by various means, a policy that is welcomed particularly by fishing interests in five of the six areas. In the seventh the reaction is varied.

Asked for observations on any difficulties or interference caused by mink, all seven hunts stated that there was little difficulty in determining whether hounds were following otter or mink. Two thought that where mink became numerous the otter became scarce, and two other hunts thought that mink might kill otter cubs or otherwise disturb breeding holts, but both ideas were put forward rather as suggestions worth looking into and did not have positive evidence in support. The Culmstock stated that on average 40 per cent of their mink finds were killed. The keeping of exact records of finds and kills of mink by otter hunts would be valuable in estimating the extent of human pressure on the mink population. Also as a mink population indicator it might produce evidence on the relative changes in the mink and otter populations.

\section{Mediterranean Monk Seal Reports}

Recent reports indicate that the Mediterranean monk seal is 'still common' along the coasts of Morocco, both Atlantic and Mediterranean, says $\mathbf{M}$. Jean Boulva in an interim report on his survey for the IUCN Seal Group. 'Fishermen say that they are often seen at the mouth of small rivers', and one was killed by a fisherman as recently as September 1973. Killing by fishermen is of course one of the main reasons for it being endangered. However, in Corsica, where monk seals used to be common, recent searches have found none. At the eastern end of the Mediterranean Professor Ben Tuvia, of Jerusalem University, says that local fishermen have seen seals in several places along the Israeli coast, and 'it is evident that one or two colonies have established themselves'. From Greece comes a report of a breeding colony in the Aegean Sea between Crete and the Cyclades.

\section{Endangered in the Marquesas}

Several endemic bird species in the Marquesas and other islands of French Polynesia are in danger of extinction, according to David T. Holyoak, writing in Biological Conservation. They include the Marquesan pigeon, with under 100 birds, ultramarine lorikeet (a few hundreds), Tahiti flycatcher (very rare and localised), and the Tuamotu sandpiper, found only on a few small atolls and threatened by introduced rats. Feral domestic animals are a large part of the cause - cattle, sheep, goats and pigs-and these threaten plants and insects too. Some islands have lost four-fifths of their original forest cover. Shooting, disease (avian malaria), and, if they cannot be stopped, French underground atomic tests are all serious threats.

\section{Project Javan Tiger}

Fewer than $15 \mathrm{Javan}$ tigers are believed to survive, all in eastern Java, in the Meru Betiri Forest Reserve area. As part of Project Tiger, WWF in collaboration with the Indonesian Government has started a project to save this race from extinction. A biologist will study the tigers and their habitat, and guards are being increased and equipped with vehicles. The Javan tiger is one of the smallest of the eight tiger forms, rather dark in colour and with fewer stripes which sometimes become spots. 